studies. The Advisory Council has expressed the opinion that the research associations should be free to undertake investigations, including economic and sociological studies, in any field of science and considers that the linking of physical science and engineering with economic studies within industry holds much promise for the future. The Development Commission is also able to make grants from the Development Fund for investigations and surveys of special rural problems and has already made grants for surveys of small-scale industries in country towns in various regions.

From the Colonial Development and Welfare Funds some $£ 776,000$ has been available for social science and economic research, and a Colonial Social Science Research Council has been set up to administer grants for such purposes. The Council has already established three research institutes-in the West Indies, and in East and West Africa-while the work of the existing Rhodes-Livingstone Institute in Central Africa has been expanded by a grant of $£ 100,000$ over five years. Research into economic problems affecting the Colonies is supervised and supported by the Colonial Economic Research Com. mittee. With minor exceptions the Departments of State dealing with economic and social affairs have taken little direct interest in research in this field, although some, like the Home Office and the Ministry of Health, have specific powers under recent Acts to commission or make grants for research. The recent report of the Committee on Qualifications of Planners stressed the need for the social sciences to contribute to the work of the Ministry of Town and Country Planning; but the activities of the very few research officers of the Ministry are neither properly coordinated nor, for the most part, concerned with any but short-term questions. The Ministry of Education carries out no research but has made grants of more than $£ 20,000$ since the end of the War to the National Foundation for Education and Research, which, however, is left free to plan its own research and has an income of $£ 8,000-9,000$ a year, chiefly from corporate subscriptions.

Of the work of the so-called 'economic' Departments, including under this head the General Register Office, the broadsheet remarks that the immense amount of work of interest to the social scientist is handled by the Departments concerned rather as technical processes than as research jobs. One particular project mentioned is the study of industrial location which, in 1948, the Industrial Location Division of the Board of Trade invited the National Institute of Economic and Social Research to undertake. There are also the various Commissions, such as the Monopolies Commission and the Royal Com. missions on Population and on the Press, which have instituted extensive inquiries, and the Government Social Survey, which was established in 1946 as a permanent part of the machinery of government, is also participating in the wider research field. The Committee on Industrial Productivity, set up in December 1947, was given a Panel on Human Factors affecting Productivity; and, although the parent Committee has now been dissolved, the work of the Panel is being continued, divided between the Medical Research Council and the Department of Scientific and Industrial Research.

The general conclusion reached by Planning in these broadsheets is that the work being carried on in the social sciences has so far been more impressive in scale than in quality. Some concern is expressed that the expansion of the teaching facilities in the social sciences at the universities will not of itself attract a sufficient proportion of the best undergraduate material or provide adequate research opportunities for the newly trained people. There are also many social and economic problems which still await systematic investigation. The independent research institutes have also an essential contribution to make to the advancement of research in the social sciences, particularly on more 'applied' problems and where team-work by people trained in different disciplines is required. The administration of funds in support of such institutes would be more conveniently conducted by a Social Science Research Council, and Political and Economic Planning suggests that the establishment of such a Council should be reconsidered in the light of a full and critical examination of the work and needs of these research institutes. Finally, the broadsheet welcomes the decision of a representative group of social scientists to establish a new professional association to bring together all those who are interested in the scientific study of society and to undertake the various functions appropriate to an organization with this object. Such a body should have an excellent opportunity of raising the standards and the prestige of the particular social sciences with which it will be concerned.

\section{FUTURE OF THE OVERSEAS FOOD CORPORATION}

SINCE the second annual report of the Overseas $\checkmark$ Food Corporation was issued last autumn, both the Corporation and the Government have accepted, in their main essentials, the recommendations in the report of the Kongwa Working Party for restriction of cultivation over the next three years to about 12,000 acres. These recommendations were also taken into account by the Corporation in preparing a revised long-term plan for the East African Groundnut Scheme. This plan has now been issued as an appendix to a White Paper on the Future of the Overseas Food Corporation* in which the Government announces its decision to write off the $£ 36$ millions already expended on the scheme and to transfer to the Colonial Office the responsibility for the revised plan which is now regarded as a scheme of large-scale experimental development to establish the economics of clearing and mechanized, or partly mechanized, agriculture under tropical conditions. Even on the modified basis now proposed, the scherne cannot fail to be an important contribution to the economic development of Tanganyika, and the results of the experiments being undertaken may be of value in many other tropical territories.

The Corporation's new proposals cover a period of seven years up to 1957. They envisage no further land-clearing at Kongwa or Urambo after the end of 1950. Of the 90,000 acres cleared at Kongwa, about $\mathbf{2 4 , 0 0 0}$ acres are to be set aside for agriculture, of which 12,000 will be under crop each year, the remainder of the cleared land being available for grazing. The object is to conduct fully costed fieldscale trials on a limited acreage for three years, when a further review will be made, in the light of the

* Overseas Food Corporation. The Future of the Overseas Food Corporation. (Cmd. 8125.) Pp. 20. (London: H.M. Stationely office, 1951.) 9d. net. 
results achieved, of the possibility of again extending arable agriculture over some or all of the remainder of the cleared land. It is not expected that more than 45,000 out of the 65,000 acres cleared at Urambo will be available for agriculture for the harvest of 1951 ; but 60,000 acres will be ready later. Of the 20,000 acres felled in the Southern Province, 7,000 acres will be available for agriculture for the 1951 harvest, and during the current wet season a further 40,000 acres are being felled with the two landclearing teams built up for that purpose. Thereafter, the Corporation proposes drastically to reduce the tractor force to the minimum required to complete the remaining operations on this 40,000 acres and to adopt a slower and cheaper method of land clearing involving the substitution of hand labour for part of the work at present done by machines. Under this scheme the same tractor force might be expected to fell an additional 15,000 acres of land per year, and the Corporation contemplates that the same acreage would be brought into cultivation each year, giving by 1957 a total of 105,000 acres fully cleared for agriculture and a further $35,000-45,000$ acres in various stages of preparation. In this revised scheme all three areas, with one exception at Kongwa, will be farmed in units of 1,500-6,000 acres, under intensive supervision by men who can gain an intimate knowledge of the land which they farm, instead of the 30,000-acre units originally proposed. The Corporation stresses the need for continuity of agricultural operations over a period of at least seven years in the interests both of efficiency and of the morale of the staff which, it is now admitted, has suffered from past uncertainties and changes of plan.

The Government is satisfied that some assurance of continuity is reasonable and indicates its firm intention, provided the costs do not greatly exceed the estimates, that funds should be provided to enable farming operations to continue for seven years. It approves the proposal for a review in 1954 before deciding on what scale further felling and clearing should be undertaken. It is estimated that over this seven-year period a further $\mathfrak{£} 6$ million will be required, without allowing for any contingencies or for any bush clearing after 1954. While the Corporation does not consider that on the basis of the new plan its needs alone would justify the com. pletion of the new part of Mtwara, in the light of decisions by the Tanganyika Government and the East African Railways and Harbours Administration to construct and improve feeder roads and to extend the railway sixty miles westward from the groundnut area, the Corporation has agreed, with the concurrence of the Government, to complete the port and the railway connecting it with the existing line.

The conclusions on which this revised plan is based are clearly stated in the appendix. First, the attempt to produce crops economically on land which has been cleared for agriculture at a great cost in money and human effort must be sustained for a sufficiently long period-put at a minimum of seven years-to show conclusive results. Second, the areas selected for development are capable of giving good yields of groundnuts and have done so on the small experimental farms. The problem yet to be solved is that of reproducing something approaching these results on a large scale. It is now concluded that the groundnut is not a plant which lends itself readily to mass methods over vast aereages, and that the attainment of economic yields demands intensive farming.
Third, the elearing of ferest and bush by wholly mechanical means from land of the type occupied by the Corporation has proved impracticable within either the time or the cost envisaged in earlier plans ; it cannot be done at an economic cost in relation to the value of the arable land created. Fourth, the Corporation considers that it would be wasteful not to utilize, at least for a maximum tree-felling effort (the most efficient and economical of the mechanized operations) during the coming wet season, the accumulated resources in communications, installations, machines and man-power which have been built up over the past three years. Finally, provision must also be made from the capital remaining at the disposal of the Corporation to cover commitments, mainly worthless, from the past and for some reserve against unforeseen contingencies in the execution of any revised plan.

The plan formulated is accordingly designed to establish, by agricultural practices and scientific experiments, a pattern of agriculture which will utilize economically all the cleared land available and which, if successful, will point the way to future development; to equip all the cleared land with permanent installations and adequate machinery and implements, without which the capital expenditure on land clearing will be wasted; and to establish that sense of permanence and stability without which no constructive objective can be achieved efficiently. The plan should also execute in the Southern Province the first stage, extending to 1957, of what may become, as a result of a later review of the economic prospects, a scheme to develop the total area capable of being serviced from Nachingwea, utilizing the installations, machinery and man-power already accumulated.

The revised plan thus appears to offer reasonable prospects of turning to the best account the resources already engaged and the experience gained. The technical and research aspect may possibly be overstressed, for the proposals scarcely bring out the importance of one lesson taught by the failure of the larger scheme, namely, the necessity of training the indigenous people in modern agricultural methods if balanced progress in development is to be achieved. Stress is rightly laid on the importance of morale and the necessity for reasonable compensation for the thousand or so European staff who will become redundant during the next three years; but something could well have been said of the part that Africans are to play in the scheme, for its ultimate success must also depend on the transformation of inexperienced Africans into successful farmers able and willing to reclaim and maintain their own land.

\section{CENTRAL DRUG RESEARCH INSTITUTE, INDIA}

$\mathrm{T}$ HE Council of Scientific and Industrial Research, India, launched six of its national laboratories during 1950. It has planned eleven such institutions so far, and the rernaining five its energetic director, Sir Shanti Swarup Bhatnagar, expects to launch in the course of 1951. The seventh of the series, dedicated to research on drugs, was the occasion of an impressive inaugural ceremony in a very picturesque setting in a Lucknow palace on the bank of the Gomati on February 17. 